УДК 37.015.31:17.022.1(091)

DOI:

Наталія Калита, кандидат педагогічних наук, доиент кафедри педагогіки і методики початкової освіти Дрогобицького державного педагогічного університету імені Івана Франка Микола Пантюк, доктор педагогічних наук, професор кафедри педагогіки і методики початкової освіти Дрогобииького державного педагогічного університету імені Івана Франка

Ірина Садова, доктор педагогічних наук, дочент кафедри педагогіки та методики початкової освіти

Дрогобицького державного педагогічного університету імені Івана Франка

\title{
ДУХОВНИЙ РОЗВИТОК ОСОБИСТОСТІ: ІСТОРИКО-ПЕДАГОГІЧНИЙ АСПЕКТ
}

У статті проаналізовано історико-педагогічний аспект феномена "духовність", “духовне виховання", "духовний розвиток особистості"; висвітлено вивчення проблеми духовного виховання особистості у філософів, педагогів, психологів минулого та сучасності; обтрунтовано, щяо духовність не зводиться до інтелектуальності, ідеальності, звернення розуму до етики, чистої моралі або аскетизму. Духовність не є й чиста релігійність, чи емочійне піднесення духу, або розумова довіра і урегульованість поведінки на цих засадах. Духовною є будь-яка діяльність, яка веде людину вперед у напрямі якоїсь форми розвитку: емоиійного, інтуїтивного, соиіального - $і$ веде, вказує на життєвість його внутрішньої сили.

Ключові слова: духовність; духовне виховання; духовний розвиток; особистість.

Jim. 15.

Natalia Kalyta, Ph.D.(Pedagogy), Associate Professor of the Pedagogy and Methods of Primary Education Department Drohobych Ivan Franko State Pedagogical University

Mykola Pantyuk, Doctor of Science (Pedagogy), Professor of the Pedagogy and Methods of Primary Education Department Drohobych Ivan Franko State Pedagogical University

Iryna Sadava, Doctor of Science (Pedagogy), Associate Professor of the Pedagogy and Methods of Primary Education Department Drohobych Ivan Franko State Pedagogical University

\section{SPIRITUAL DEVELOPMENT OF PERSONALITY: HISTORICALAND PEDAGOGICALASPECT}

The article considers the peculiarities of the spiritual development of the personality. It reveals the concepts "spiritual education", "spiritual development"; it also elucidates the study of the problem of spiritual education of the personality by philosophers, teachers, psychologists of the past and modernity. Some aspects of the spiritual development of the personality at primary school are examined.

The article substantiates that spirituality is not reduced to intellectuality, ideality, to the appeal of mind to ethics, pure morality or asceticism. Spirituality is not pure religiousness, or emotional uplift, or mental confidence and regulation of behavior on these principles. Spiritual activity is any activity that leads a person forward in the direction of some form of development: emotional, intuitive, social ones - and leads indicating the vitality of his/her inner strength.

Spirituality is a general cultural phenomenon that combines a set of value-oriented characteristics of the personality and motivated and inspired actions and deeds. Since the concept "spirituality" acquires its content in the context of the search of personal meanings and the sense of human existence, then naturally, it remains in the center of attention of both philosophers and psychologists and teachers.

The article considers the problem of spiritual development of the personality at the change of epochs, which follows the contradictions between the crises of spirituality that became the result of the transformation of social values. It is reflected in the relationship between people and the need to establish European values, which are based on the recognition of human life as the highest value. The problem of spiritual development of the personality also follows the contradictions between the process of transition of national education to the humanistic principles of the development and the absence of a systematic approach to the establishment of humanistic values as a basis of the development of individual spirituality.

It is revealed the problem of spiritual development of the personality in the pedagogical activity of philosophers, 


\section{ДУХОВНИЙ РОЗВИТОК ОСОБИСТОСТІ: ІСТОРИКО-ПЕДАГОГІЧНИЙ АСПЕКТ}

psychologists and teachers, spesifically in the works of N. Skotna, M. Savchyn, O. Sukhomlynska, K. Ushynskiy, $V$. Sukhomlynskiy, $O$. Vyshnevskiy and other scientists of the past and modernity.

A spiritually rich person is a person who lives in harmony with himself/herself and the world, who has well formed spiritual values. They are those qualities and features, life attitudes that exist for each person, that make his/ her ideal.

Keywords: spirituality; spiritual education; spiritual development; personality.

П остановка проблеми. Одним із важливих завдань Української держави виступає збереження національних інтересів, народу, виховання високоморальної, духовно розвиненої особистості громадянина. У матеріалах парламентських слухань Верховної Ради України зазначено, що “виховання дітей та молоді, формування у них системи цінностей та духовних пріоритетів $\epsilon$ першочерговим завданням навчальних закладів, а впровадження системи духовно-морального виховання дітей i молоді на засадах загальнолюдських і національних цінностей важливим соціальним замовленням держави. Саме тому в ситуації національного дефіциту почали відігравати роль християнські національні цінності, які є основою гуманістичних цінностей, що виробило людство упродовж тисячоліть”.

Тлумачення духовності більш схильне до релігійного, християнського підходу. Багато учених - філософів, педагогів - ідентифікують духовне виховання з поняттям “дух", Богом, вірою. В енциклопедії освіти зазначено, що “духовність - це категорія людського буття, якою виражається його здатність до самотворення та творення культури" [6]. Науковці вважають, духовність вищим рівнем розвитку особистості на якому основними мотиваційно-смисловими регуляторами є вищі людські цінності. О. Сухомлинська на основі аналізу праць видатних педагогів, письменників, філософів дорадянського періоду констатуе, що вони розглядали духовність як багатоаспектне явище, провідною ознакою якого вважали християнську духовність. 3 цього приводу вчена зазначає, що "в залежності від педагогічних поглядів носіїв цієі ідеї до феномена духовності долучалися і наукові, і етнологічні складові або цінності, які з часом посідали все більше і більше місця. І тому було б помилково ототожнювати палітру педагогічних поглядів лише 3 християнською догматикою. Гуманізм, раціоналізм і натуралізм поступово проступають в педагогічних творах як головні виховні орієнтири" [9].

Духовний розвиток особистості грунтується на спільній меті - вихованні гармонійно розвиненої особистості у сукупності духовного багатства, морального виховання, фізичної досконалості, естетичного виховання.
Аналіз основних досліджень. Проблема вивчення феномена духовності завжди була актуальною. Чимало студій цьому питанню присвятили філософи М. Бердяєв, С. Кримський та інші. Аспекти духовного виховання висвітлено в Декларації про християнське виховання, а також проаналізовано в працях митр. Андрея Шептицького, блаж. Любомира Гузара та ін. Вихованню духовності в системі освіти приділяли увагуК. Ушиннський,Г. Ващенко, I. Огієнко,П.Юркевич, В. Сухомлинський, О. Вишневський, М. Євтух, І. Бех, Н. Скотна, М. Савчин та інші.

Виклад основного матеріалу. Філософи, педагоги, психологи аналізували духовне виховання особистості з двох позицій - світської і релігійної. Так, М. Бердяєв розглядав духовність як специфічну людську якість, яка мотивує поведінку особистості, ії потребу в пізнанні світу, пошуку смислу життя, іï самопізнанні. Зміст духовності за вченим визначає прагнення людини до істини, правди, краси [1]. Н. Скотна розрізняє два основні розуміння поняття духовності, перше стосується тільки вір'ян і пов'язане із сакральним началом, друге тлумачить духовність як світську, атеїстичну [8].

Два полюси духовності визначає М. Савчин Божественний і людський зазначаючи, що духовність $€$ переходом від гріховного до святого. Психолог вважає, що духовність передбачає “співпрацю" різноманітних галузей науки про людину, зокрема систематичного богослов'я, філософії, психології, літератури та ін. [7].

О. Вишневський формулює проблему духовності в запитанні: “Що для нас сьогодні може стати головним ідеалом і джерелом духовності? Як відновити духовне поле суспільства i, отже, підвалини педагогіки?” [3]. 3 цього приводу зазначає, що “без Авторитету Бога і віри в Нього неможливо сьогодні відновити духовне поле суспільства, а отже і структуру виховання, неможливо наповнити новим, гуманістичним змістом, водночас і відвертатись від цієї проблеми, прикриваючись вдаваним авторитетом, пускати справу самовпливом, означає давати зелене світло всілякому богошукацтву і псевдорелігіям, що так активно захоплюють тепер духовний простір нашої свідомості і далеко не завжди ведуть людину до Бога" [3]. 


\section{ДУХОВНИЙ РОЗВИТОК ОСОБИСТОСТІ: ІСТОРИКО-ПЕДАГОГІЧНИЙ АСПЕКТ}

Учений, характеризує духовність, як “певний стан людини і суспільства, який формується, виробляється важкою працею душі самої людини і самого суспільства, з участю їх власної волі і зусиль" [2].

Аналіз праць Івана Огієнка свідчить, що він розглядав духовність у педагогічному аспекті як інтегративну властивість особистості, яка виявляється у потребі жити, творити відповідно до християнських ідеалів істини, добра і краси, як показник рівня людських взаємин, моральноестетичної, національної і громадянської позицій, здатності співчувати і виявляти милосердя [5].

На наш погляд, духовність - це гармонійне узгодження внутрішнього світу людини, душі і духу, інтегрована властивість особистості, яка дає змогу робити вільний вибір смислу життя на основі духовно-морального ідеалу; це сходження до вищих цінностей, возз'єднання образу Я 3 образом світу. Категорія духовності з позицій нового осмислення феномена людини як неподільної цілісності (тілесної, душевної, духовної), органічно пов'язаної зі Всесвітом, 3 Космосом, розглядається неоднозначно. Об'єднувальним началом у різних тлумаченнях духовності є сукупність духовних почуттів, духовних потреб, духовних цінностей, ціннісних смислів людського буття, світоглядних позицій і творчої активності, високоморальних відносин між людьми, до всього навколишнього

Зокрема. В. Сухомлинський наголошував на тому, що через засвоєння моральних, інтелектуальних, естетичних потреб у процесі діяльності особистості відбувається їі духовний розвиток [9].

Педагог зазначав, що “справжня школа - це багатогранне духовне життя дитячого колективу, в якому вихователь і вихованець об'єднані багатьма інтересами і захопленнями" [10].

Структурними компонентами процесу виховання є його зміст і мета, які в сукупності цілей і завдань становлять мету виховання, його основне педагогічне завдання; форми $і$ методи, суб'єкти педагогічної взаємодї̈, якими є вихователь та вихованець, матеріальні, духовні та соиіальні иінності, норми тощо. В розумінні духовності у В. Сухомлинського займає місце морально-етична проблематика. Він наближається до християнської тематики, починає розглядати теми й проблеми, які до того часу не були предметом педагогічної науки - це формування ставлення дитини до життя й смерті, добра і зла, тема совісті і шляхи ії формування, розуміння й усвідомлення своєї провини, необхідність каяття, формування культури людських бажань у юнаків і дівчат, їх духовної підготовки до життя.
Крім того, В. Сухомлинський розвивав культурно-освітній проєкт з виховання духовності, який значно відрізнявся від наявних педагогічних підходів самим зверненням до морально-етичної проблематики. В соціометричній виховній парадигмі, яка існувала на той час, усе було закладено у зовнішньому середовищі, а вчений запропонував новий, внутрішній механізм ціннісної регуляції і саморегуляції дитини, ї творчого розвитку, спрямований на формування усталеної домінанти-духовності.

Такі компоненти духовності визначає С. Щербина: “потребово-ціннісний, пізнавально-інтелектуальний, вольовий, вчинко-діяльнісний, почуттєвоемоційний, гуманістичний, естетичний” [14].

На думку К. Ушинського, “Духовний розвиток, духовне виховання людини зокрема і народу в цілому здійснюється не лише школою, але декількома, великими вихователями: природою, життям, наукою і релігією" [12].

Духовний розвиток особистості - це індивідуальне залучення особистості до духовної культури суспільства, оволодіння загальнолюдськими, загальнокультурними, соціокультурними, національними цінностями, й досвідом людства в процесі духовнопрактичної діяльності та самостійного творчого розвитку кожної особистості.

Духовний розвиток особистості як “формування та реалізацію таких вищих потреб людини: у пізнанні світу, себе, сенсу життя; у визнанні та повазі власної особистості з боку інших осіб; у сприйманні та створенні краси (тобто естетичну); у доброчинстві та ствердженні справедливості (тобто гуманістичну), у психічному та особистісному вдосконаленні" розглядає Ж. Маценко [4].

Костянтин Ушинський констатує, що є “навмисна виховна діяльність - школа, вихователь і наставники”, однак “набагато сильнішими вихователями є вихователі не навмисні: природа, сім'я, суспільство, народ, його релігія і його мова, словом, природа і історія в найширшому значенні цих широких понять” (курсив К.У. - прим. Н.К.) [13]. Педагог переконаний, що “духовний розвиток, духовне виховання людини, зокрема і народу в цілому здійснюється не лише школою, але декількома, великими вихователями: природою, життям, наукою і релігією" [12].

Як педагогічну взаємодію, а школу як живий та одухотворений союз особистостей, а не “мертву“ школу, в якій діти підпорядковані авторитету вчителя, а одне про одного не відають, не пам'ятають і не турбуються розглядає процес навчання і виховання П. Юркевич [15].

За К. Ушинським, у прагненні досконалості 
зосереджене намагання людини не лише засвоювати, але й творити соціальні, матеріальні та духовні изінності. Такими цінностями педагог визначає релігію, рідне слово, мову, мораль, душевну працю, здоров'язбережувальну педагогіку (в К. Ушинського - “здравая педагогика").

Головними суб'єктами виховного впливу на людину і суспільство К. Ушинський вважає Церкву, а також представників духовної та світської освіти. Педагог формулює категоричну вимогу: “необхідно, щоб духовні особи, які присвятили себе виховній діяльності, були хорошими педагогами, і з другого боку, необхідно також, щоб світські особи, які беруться за виховання, особливо простого народу, були не тільки хорошими педагогами, але й справжніми християнами за своїми устремліннями i переконаннями, наскільки переконання людини відкриті для споглядання іншими людьми" [13].

Неодноразово підкреслюючи неприпустимість меркантильного, практично-утилітарного ставлення до навчання і виховання. педагог переконував, що марнославство у вихованні $\epsilon$ в сім'ях, де “зазвичай дітей не виховують, а готують (курсив К.У. - прим. Н.К.), чи не 3 колиски, до вступу у той чи той заклад освіти, чи до виконання умовних вимог того суспільного кола, до якого, на думку батьків, будуть належати їхні діти" [13]. Саме тут, на його думку, бере початок марнославне захоплення вивченням іноземних мов, заняття музикою при відсутності у дитини задатків до неї, репетиторська дресура тощо. К. Ушинський осуджує ту сімейну виховну діяльність, мотивами якої є прагнення батьків відповідати вимогам аристократизму, досягнути вищого щабля на соціальній драбині, “дати своїм дітям таку освіту, щоб вони стали вище, аніж ми в суспільстві, щоб вони вийшли з того становища, в якому ми самі стоїмо” [13]. Учений констатує, що такі зусилля не $\epsilon$ турботою батьків дати дітям кращу освіту, аніж ту, яку отримали свого часу вони самі, це лише бажання батьків бути не самими собою, утвердитися у суспільстві, використовуючи власну дитину як річ, засіб, нехтування її особистістю.

Серед безлічі визначень духовності, представленими в сучасній науці, домінує думка про піднесення особистості над фізіологічними потребами, етичним розрахунком, раціональною рефлексією. Духовність - це те вище, до чого прагне людина.

Висновки. На основі аналізу літератури 3 означуваної проблеми, можемо стверджувати, що вчені не мають одностайного визначення щодо поняття духовності та духовного розвитку особистості.

Подальші перспективи дослідження мають можливість розширювати огляд сучасного стану та впровадження поняття духовності в сфери освіти, культури та ін.

\section{ЛІТЕРАТУРА}

1. Бердяев Н. А. Духовное состояние современного мира. Новый мир. 1990. № 1. С. 34-38.

2. Вишневський О. I. На шляху реформ. Актуальні питання сучасної украӥнської освіти та змісту виховання. Вибрані науковопубліциистичні праці. Дрогобич, 2005. С. 140.

3. Вишневський O.I. Теоретичні основи сучасної української педагогіки. Посібник для студентів вищих навчальних закладів. Дрогобич, 2003. 528 с. 31

4. Маценко Ж. М. Духовність: феномен психології та об'єкт виховання. Київ, Освіта України. 2010. 100 с.

5. Огієнко І. Тимошик М. Українська культура / Упор., авт. передмови і коментарів. Київ: Наша культура і наука, 2002. 340 с

6. Охрімчук Р.М. Духовність. Енциклопедія освіти. 2008 С. 244-245.

7. Савчин М. В. Духовний потенціал людини: навчальне видання (монографія). Вид. 2-ге. ІваноФранківськ, 2010. С. 141.

8. Скотна Н. В. Особа в розколотій цивілізації: освіта, світогляд, дії. Львів, 2005. С. 345-346.

9. Сухомлинська О.В. Духовно-моральне виховання дітей та молоді: загальні тенденції й індивідуальний пошук. Київ: Добро. 2006. С.13.

10. Сухомлинський В. Вибрані твори: у 5-ти т. Київ: Радянська школа, 1977.

11. Сухомлинський В. О. Методика виховання колективу. Київ, 1971.

12. Ушинский К. Вопросы о народных школах. Собрание сочинений: В 11 т. Т. 2. МоскваЛенинград: Изд. Аккад. пед. наук РСФСР, 1948. С. $250-265.655 \mathrm{c}$.

13. Ушинский К. О нравственном элементе воспитания. Собрание сочинений: В 11 т. - Т. 2. Москва-Ленинград: Изд. Аккад. пед. наук РСФСР, 1948. С. $425-489.655$ с.

14. Щербань П. М. Погляди К. Д. Ушинського на зміст і методику виховання та навчання дітей в сім’ї та школі. Освіта. 2003. 16-23 лип. (№ 33). C. 4-5.

15. Юркевич П. Серце і його значення в духовному житті людини за вченням Слова Божого. Хроніка - 2000. Украӥнський культурологічний альманах. Випуск $39-40$. Київ: ЗАТ “ВІПОЛ”, 2000. С. 563 - 573. 


\section{REFERENCES}

1. Berdiaev, N.A. (1990). Dukhovnoe sostoianye sovremennoho myra [The spiritual state of the modern world]. New world. No. 1. pp. 34-38. [in Russian].

2. Vyshnevskyi, O. I. (2005). Na shliakhu reform [On the way of reforms]. Vital questions of modern Ukrainian education and the content of education. Selected scientific and journalistic works. Drohobych, p. 140. [in Ukrainian].

3. Vyshnevskyi, O.I. (2003). Teoretychni osnovy suchasnoi ukrainskoi pedahohiky [Theoretical foundations of modern Ukrainian pedagogy]. Handbook for students of higher educational institutions. Drohobych, p. 528. [in Ukrainian].

4. Matsenko, Zh. M. (2010). Dukhovnist: fenomen psykholohii ta obiekt vykhovannia [Spirituality: the phenomenon of psychology and the object of education]. Kyiv, p.100. [in Ukrainian].

5. Ohiienko, I. \& Tymoshyk, M. (2002). Ukrainska kultura [Ukrainian culture]. Kyiv, p. 340. [in Ukrainian].

6. Okhrimchuk, R.M. (2008). Dukhovnist [Spirituality]. Encyclopedia of Education. pp. 244245. [in Ukrainian].

7. Savchyn, M. V. (2010). Dukhovnyi potentsial liudyny [The spiritual potential of a person]. Vol. 2 . Ivano-Frankivsk, p. 141. [in Ukrainian].

8. Skotna, N. V. (2005). Osoba v rozkolotii tsyvilizatsii: osvita, svitohliad, dii [A person in a divided civilization: education, world outlook, actions]. Lviv, pp. 345-346. [in Ukrainian].
9. Sukhomlynska, O.V. Dukhovno-moralne vykhovannia ditei ta molodi: zahalni tendentsii y indyvidualnyi poshuk [Spiritual and moral education of children and youth: general tendencies and individual search]. Kyiv, p.13. [in Ukrainian].

10. Sukhomlynskyi, V. (1977). Vybrani tvory: u 5ty t. [Selected works: in 5 vol.]. Kyiv. [in Ukrainian].

11. Sukhomlynskyi, V. O. (1977). Metodyka vykhovannia kolektyvu [Methods of the education of collective]. Kyiv. [in Ukrainian].

12. Ushinskiy, K. (1948). Voprosyi o narodnyih shkolah [Questions about the public schools]. Collection of works: In $11^{\text {th }}$ volumes. Vol. 2. Moscov-Leningrad, pp. 250 - 265. [in Russian].

13. Ushinskiy, K. (1948). O nravstvennom elemente vospitaniya [About the moral element of education]. Collection of works: In $11^{\text {th }}$ volumes. Vol. 2. Moscov-Leningrad, pp. 425 - 489. [in Russian].

14. Shcherban, P. M. (2003). Pohliady K. D. Ushynskoho na zmist i metodyku vykhovannia ta navchannia ditei v simi ta shkoli [K. Ushynskyi's views on the content and methods of education and training of children in the family and at school]. Education. 16-23 (No. 33). pp. 4-5. [in Ukrainian].

15. Iurkevych, P. (2000). Sertse i yoho znachennia v dukhovnomu zhytti liudyny za vchenniam Slova Bozhoho [Heart and its significance in the spiritual life of a person according to the teaching of the Word of God]. Chronicle - 2000. Ukrainian culturological almanac. Vol. 39 - 40. Kyiv, pp. 563 -573. [in Ukrainian].

Стаття надійшла до редакції 23.12.2020

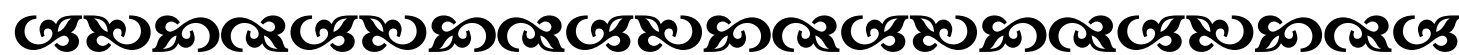

“Ледагогічна ідея - це повітря, в яқому розправляє қрила педагогічна творчість". Василь Сухомлинський педагог, публіиист, письменник, поет

"У справі виховання варто було б подбати про те, щоб разом із піклуванням про розвиток індивідуальних здібностей кожної людини виховувати в ній почуття відповідальності по ставленню до свойх близьких".

Альберт Ейнштейн один з найвизначніших бізиків ХХ століття. Аауреат Нобелівської премї̈ 1921 року

“Яюдина, що володіє вродженим талантом, відчуває найбільще щастя тоді, коли використовує ией талант”.

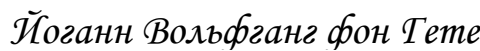
німеиьқий поет

\section{G58080}

